\title{
Bacterial Predation on Cyanobacteria
}

\author{
Antje Bauer Karl Forchhammer \\ Interfaculty Institute of Microbiology and Infection Medicine, Eberhard Karls Universität, Tübingen, Germany
}

\section{Keywords}

Bacteria · Cyanobacteria · Survival strategies · Predatory bacteria. Predation

\begin{abstract}
Predatory bacteria gained interest in the last 20 years. Nevertheless, only a few species are well characterized. The endobiotic predator Bdellovibrio bacteriovorus invades its prey to consume it from the inside, whereas Myxococcus xanthus hunts as a whole group to overcome its prey. Both species were described to prey on cyanobacteria as well. This minireview summarizes the findings of the last 20 years of predatory bacteria of cyanobacteria and is supplemented by new findings from a screening experiment for bacterial predators of the model organism Anabaena variabilis PCC 7937. Known predatory bacteria of cyanobacteria belong to the phyla Proteobacteria, Bacteroidetes, and Firmicutes and follow different hunting strategies. The underlying mechanisms are in most cases not known in much detail. Isolates from the screening experiment were clustered after predation behaviour and analyzed with respect to their size. The effect of predation in high nitrate levels and the occurrence of nitrogenfixing cells, called heterocysts, are addressed.

(C) 2021 The Author(s)

Published by S. Karger AG, Basel
\end{abstract}

\section{Introduction to Microbial Predation and Its Impact}

Life on earth is a sensitive system of countless species that live together in a certain balance. They interact with each other through all domains of life, and the interactions can be beneficial, disadvantageous, or even neutral (Fig. 1). Mutualism describes a win-win situation of the participating organisms. By digestion, synthesis, or photosynthesis, they provide each other nutrients, growth factors, or energy. They can also act as a shield to environmental changes or even enemies [Boucher et al., 1982]. In commensal and amensal relationships, one organism benefits (commensal) from or is harmed (amensal) by the other. The latter is not affected at all. During competition, both organisms harm each other. In marine sponges for example, Esteves et al. found that a Bacillus subtilis strain degrades the host sponge. This reduces the living environment for commensal Pseudovibrio strains, which in turn inhibit B. subtilis or its degrading enzymes [Esteves et al., 2017].

Besides sharing benefits like in mutualism or commensalism, in interactions such as parasitism and predation, one organism benefits and harms the other. In the literature, the terms predator and parasite are not clearly delimited from each other. In this article, predation describes the straightforward killing of a prey to use its com-

Correspondence to:

Karl Forchhammer, karl.forchhammer@uni-tuebingen.de karger@karger.com www.karger.com/mip

Karger $\stackrel{\text { ' }}{=}$

BOPEN ACCESS
2021 The Author(s)

Published by S. Karger AG, Basel

This is an Open Access article licensed under the Creative Commons Attribution-NonCommercial-4.0 International License (CC BY-NC) (http://www.karger.com/Services/OpenAccessLicense), applicable to the online version of the article only. Usage and distribution for commercial purposes requires written permission. 


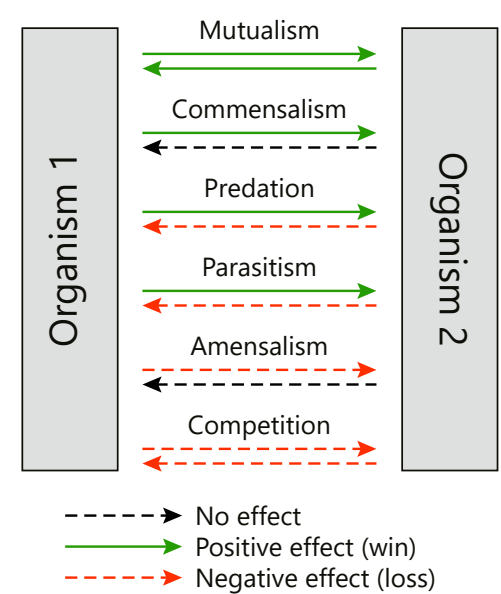

Fig. 1. Possible interactions between two organisms. Relations can be beneficial or harmful to one or both organisms. In some cases, only one organism is affected.

ponents as nutrients. Parasitism, on the other hand, defines a prolonged exploitation of a host metabolism. Well-known examples of parasites are worms and ticks with animals as hosts.

Microbacterial communities are complex ecosystems that are affected by many different factors. The dynamics of populations is determined by environmental factors like dissolved organic matter, temperature, light, and $\mathrm{pH}$. An increase in nitrate levels due to agricultural fertilization can contribute to cyanobacterial bloom formation. Blooms pose a risk for humans, animals and the whole ecosystem [reviewed by Huisman et al. [2018]. Microbacterial communities, which blooms are, can be regulated top-down by grazers, viruses, and predatory bacteria. Gilbert et al. [2012], for example, showed that differences in day length during the seasons account for $65 \%$ of the changes in populations on a marine coastal site. Another study identified salinity as a driver for population changes [Bouvier and del Giorgio, 2002]. To predict multispecies relationships, the generalized Lotka-Volterra model is used, which describes the growth rates of populations of prey and predator over time [Gonze et al., 2018]. According to this model, the numbers of prey and predator depend on reproduction rates and the interaction between the species. In simple systems of only two species, the populations of prey and predator oscillate with a phase shift, indicating a rising number of predators as a result of a previous rise in the number of prey cells. This is followed by a drop of the prey numbers and then of the predator. The presence of a predator in a microbial com- munity affects the population of the prey and probably of other bacteria, as well. But following the Lotka-Volterra model, the populations will be balanced in an oscillating way, if no other unpredicted events like fertilization, invasion of foreign species, or climate change happen.

The ability to perform photosynthesis and to fix atmospheric nitrogen makes cyanobacteria an excellent source of nutrients. Many organisms such as diatoms, sponges, corals, lichens, and mosses benefit from this (reviewed by Usher et al. [2007]). Predation of cyanobacteria by grazing protozoa, like amoeba for example, was reported many times [Wright et al., 1981; Dryden and Wright, 1987; Simkovsky et al., 2012; Ma et al., 2016]. Fungi prey on cyanobacteria, too. The white-rot fungi Phanerochaete chrysosporium (phylum: Basidiomycota) preys on Oscillatoria spp. and Microcystis aeruginosa using direct cellcell contact. Rhizosiphon spp. (phylum: Chytridomycota) infiltrate Anabaena macrospora to reproduce over several infection stages [Gerphagnon et al., 2013; Zeng et al., 2015; Zeng et al., 2020]. So far, no predatory archaea are known.

The presence of predatory bacteria, however, has only gained attention the last 20 years (results for "predatory bacteria" rose from 10 results in 2000 to 83 in 2020, in PubMed, December 9, 2020).

Predatory bacteria depend on living prey (obligate predator) or can also live from lysed prey cells (saprophytic). Facultative predatory bacteria do not depend on prey and can grow in a nutrient-rich environment. To lyse the prey, predatory bacteria follow different hunting strategies: endobiotic predation, epibiotic predation, and the predations as a group.

\section{Endo- and Epibiotic Predation: Examples of the Genus Bdellovibrio}

One of the best known predatory bacteria is the endobiotic predator Bdellovibrio bacteriovorus. While searching for bacteriophages, it was isolated by Stolp and Petzold [1962] as a lytic bacterium. A year later, Stolp and Starr [1963] defined the lytic bacterium as B. bacteriovorus. Until 3 years ago, it was assigned to the Deltaproteobacteria, but in 2017 the order Bdellovibrionales was reclassified to Oligoflexia in the phylum Proteobacteria [Hahn et al., 2017]. B. bacteriovorus lyses exclusively Gram-negative bacteria like E.coli or the cyanobacterium Phormidium luridum [Burnham et al., 1976], but the prey spectrum varies from isolate to isolate [Stolp and Starr, 1963]. B. bacteriovorus follows a two-stage predation 


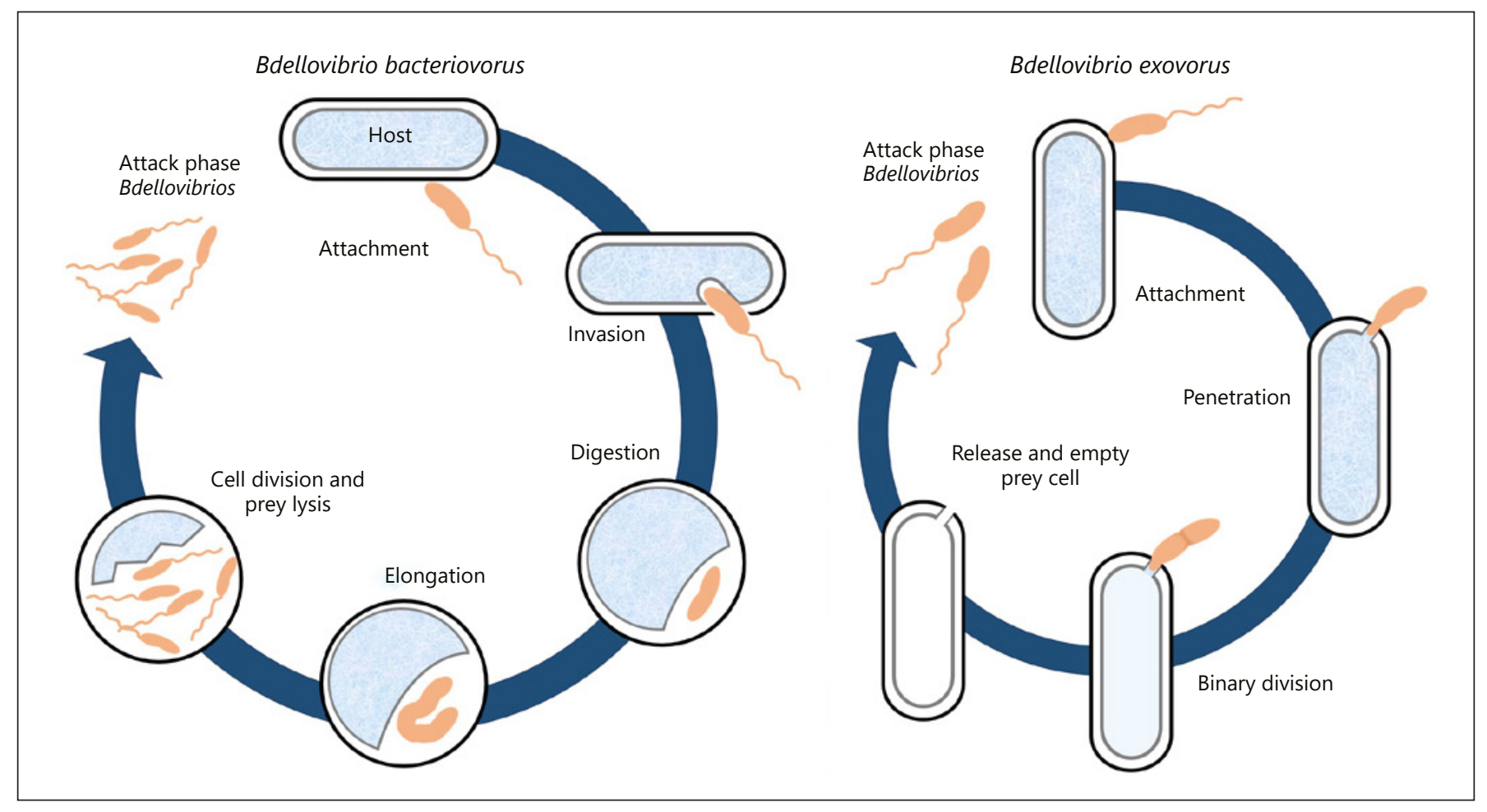

Fig. 2. Life cycle of B. bacteriovorus and B. exovorus. B. bacteriovorus follows an endobiotic lifestyle: it penetrates the periplasm of the prey cell and consumes it from the inside, elongates, divides, and sets the progeny free by lysing the host cell. B. exovorus is an epibiotic predator: it attaches on the surface of the prey cell and consumes the cytoplasm from the outside. While being attached to the prey cell, B. exovorus reproduces by binary fission. After division, it leaves the empty prey behind.

strategy starting with an attack phase, which leads up to a periplasmic growth phase (Fig. 2). In the attack phase, Bdellovibrio swims rapidly to find randomly new prey following chemoattractants. These compounds signal bacterial populations but not necessarily prey [Straley and Conti, 1977; Straley et al., 1979]. As soon as it finds its prey, it starts excreting enzymes like glycanase and peptidase to enter the cell [Thomashow and Rittenberg, 1978b]. Kuru et al. [2017] showed the formation of a "reinforced circular port-hole" through which the predator enters the prey. As a signal that is later needed for lysing exclusively the host, deacetylases alter the host-cell wall [Thomashow and Rittenberg, 1978a]. From the inside, that is, the periplasm, B. bacteriovorus degrades the cellular components and consumes them to reproduce itself. Due to the activity of endopeptidases that cleave crosslinks in the peptidoglycan, the prey cell changes its shape to a sphere. The so called bdelloplast prevents from double infection [Lerner et al., 2012]. After a phase of elongation, Bdellovibrio separates into single cells that leave the prey by producing the lysozyme DslA. This specifically destroys the previ- ously deacetylated host cell wall, which prevents self-destruction of the predator [Harding et al., 2020]. The released progeny starts the cycle again. Although Bdellovibrio is regarded as an obligate predatory bacterium, there are variants that grow host independent in nutrient-rich media. As type IV pili are essential for predatory activity of Bdellovibrio [Evans et al., 2007], Capeness et al. [2013] proposed that a reduced type IV pili formation led to the host-independent lifestyle.

The complete genome of B. bacteriovorus covers 3.8 mega base pairs (Mbp) on one chromosome. Over 250 hydrolytic enzymes were found, including 150 proteases/ peptidases [Rendulic et al., 2004]. In a recent study, the authors ran a genome-scale metabolic model. They also included metabolic information from genome annotation and biochemical data. The metabolic reactions were clustered into 12 different functional categories. The largest category included catabolic reactions (37\%) like the degradation of peptidoglycan and other reactions of the cell envelope metabolism [Herencias et al., 2020]. An in silico analysis found 14 auxotrophies for amino acids and 
several cofactors like riboflavin, nicotinamide, putrescine, and lipoate [Herencias et al., 2020]. This shows how important it is for Bdellovibrio to overcome its prey and to be able to compensate for the auxotrophies.

Bdevollvibrio exovorus is an epibiotic predator and follows another strategy. It was isolated from sewage in Canada, living on Caulobacter crescentus and was described as a novel species of Bdellovibrio in 2013 [Koval and Hynes, 1991; Koval et al., 2013]. The life cycles of the Bdellovibrios are similar. The difference is that $B$. exovorus does not enter the prey cell but attaches outside of it and consumes the cytoplasm. While being attached to the prey cell it reproduces by binary fission. After division, it leaves the empty prey behind (Fig. 2). The cell shape of the prey remains the same and no bdelloplast is formed. In contrast to $B$. bacteriovorus, the prey range of $B$. exovorus is limited to Caulobacter spp. [Koval et al., 2013]. Besides the known Bdellovibrios, there are Bdellovibrio and Like Organisms (BALOs). BALOs are small obligate predators that follow the same hunting strategy as $B$. bacteriovorus and B. exovorus [Rotem et al., 2014]. Caiola and Pellegrini [1984] isolated a BALO strain that can prey on the cyanobacterium Microcistis aeruginosa. Like $B$. bacteriovorus, it penetrates the prey cell to lyse it from within.

\section{Hunting as a Group: The Example Myxococcus xanthus}

An example of group-hunting predatory bacteria is the well-described Myxococcus xanthus, a rod shaped, Gramnegative soil bacterium belonging to the Deltaproteobacteria. It has auxotrophies for valine, leucine, and isoleucine [Bretscher and Kaiser, 1978] and needs to take up those amino acids from prey cells. However, as a saprophytic bacterium, it is also able to grow on dead prey bacteria [Shimkets, 1984]. The prey spectrum spans from soil bacteria including the plant pathogen Pectobacterium carotovorum, over the cyanobacterium $P$. luridum, to clinically relevant species like Klebsiella pneumoniae or Candida albicans [Burnham et al., 1981; Rosenberg and Varon, 1984; Morgan et al., 2010; Livingstone et al., 2017]. Because of this broad prey spectrum, Thiery and Kaimer [2020] suggested the involvement of different lysis mechanisms, which act alone or together. For successful lysis of prey, a direct physical contact is necessary [McBride and Zusman, 1996; Pan et al., 2013; Zhang et al., 2020]. The life cycle of $M$. xanthus comprises four main steps: free living Myxococci swarm out to find prey bacteria,

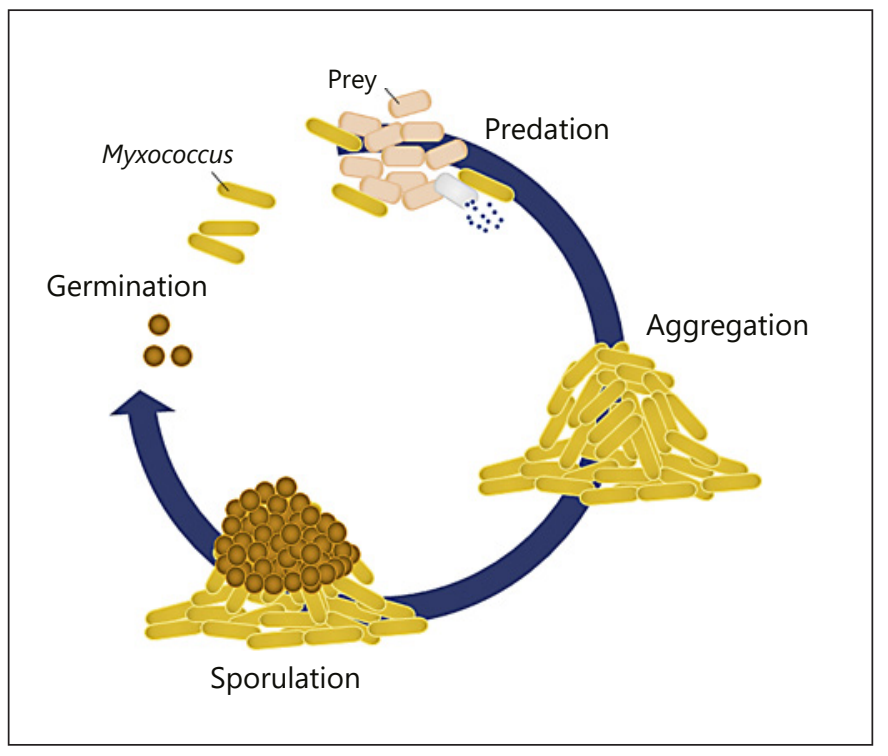

Fig. 3. Life cycle of M. xanthus. Gliding Myxococcus cells find prey and lyse them. When conditions get unfavourable, cells start to aggregate, and sporulation starts. Spores are released and germinate if conditions are favourable.

consume the prey, aggregate when nutrients diminish and form myxospore containing fruiting bodies. Those germinate when the conditions are favourable again (Fig. 3). To find prey, Myxococci follow acyl homoserine lactones (AHLs), which are used from different bacteria as quorum sensing signals. In presence of AHLs, M. xanthus sporulation is hindered and germination is promoted, both leading to an increase in predatory active cells [Lloyd and Whitworth, 2017]. Because Myxoccoci need to find the prey actively, motility is an important feature in predation. Myxococcus uses two kinds of motility: social or S-motility is a movement of multiple cells and is mediated by retracting type IV pili (TFP) at one cell pole [Kaiser, 1979; Merz et al., 2000; Sun et al., 2000]. Myxococcus cells are covered with an extracellular matrix (ECM) consisting of the TFP, lipopolysaccharides, and fibrils [Bowden and Kaplan, 1998]. The fibrils are formed by proteins and exopolysaccharides (EPS) and connect the cells to each other [Behmlander and Dworkin, 1994]. The carbohydrates of the EPS are the point of attachment for the TFP. In case of attachment, the TFP retract, which leads to a movement towards the other cell [ $\mathrm{Li}$ et al., 2003]. The presence of EPS is crucial for S-motility and fruiting body formation. S-motility, in turn, is necessary for efficient predation [Lu et al., 2005; Pérez et al., 2014]. Adventurous or A-motility is a single cell movement by gliding and intends to explore the environment and to 


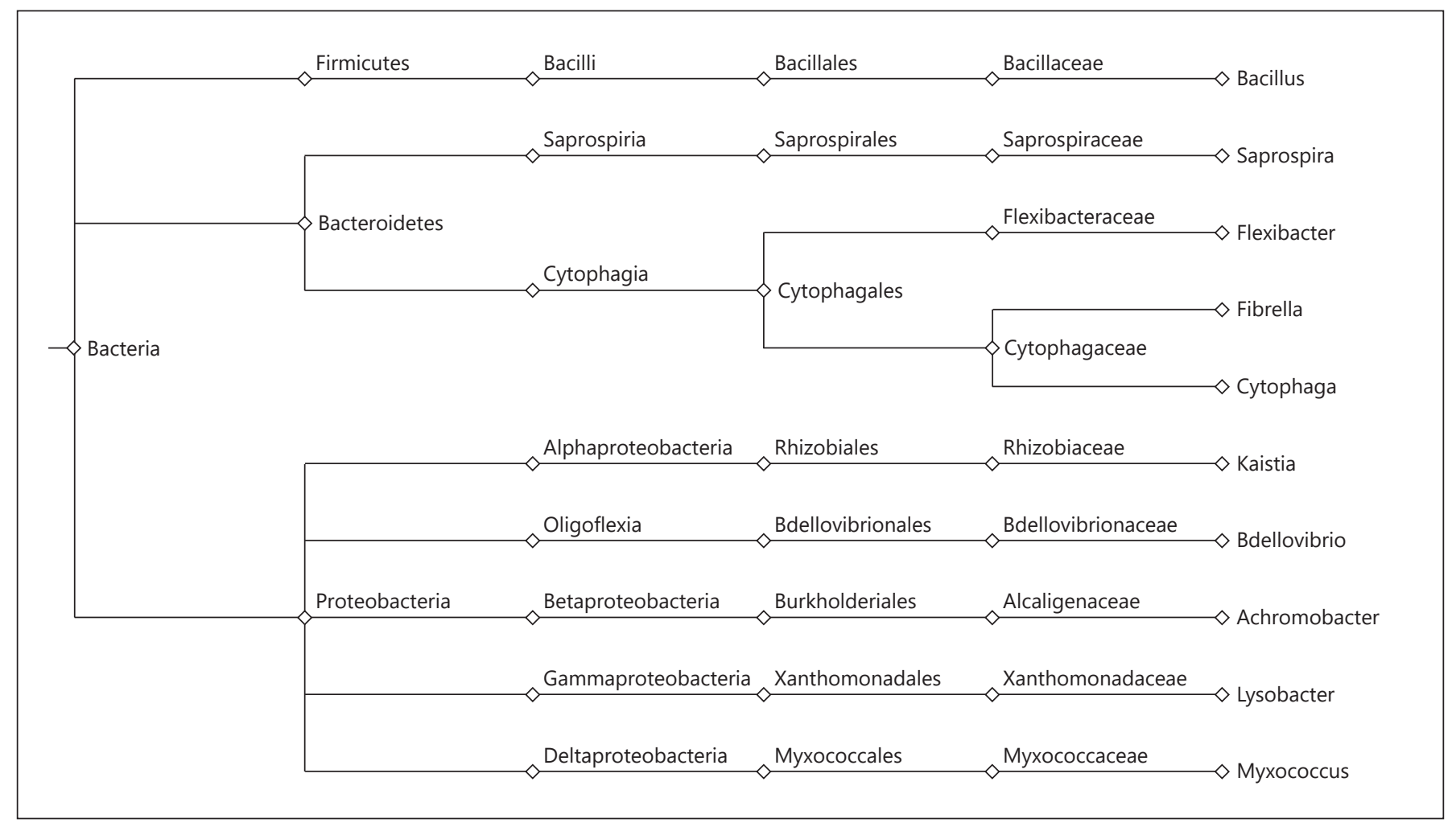

Fig. 4. Cladogram of predatory bacteria of cyanobacteria. Most predatory bacteria of cyanobacteria belong to the phyla Bacteroidetes and Proteobacteria, except Bacillus sp., which belong to the phylum Firmicutes. Tree by NCBI CommonTree. Tree Viewer: Dendroscope [Huson and Scornavacca, 2012].

find new habitats. The underlying mechanism is not completely clear yet. One hypothesis was that Myxobacteria glide by the extrusion of slime resulting in a jet propulsion and a thrust forward [Wolgemuth et al., 2002; Spagnolie and Lauga, 2010]. But experiments with motility mutants showed that slime is also produced in non-motile cells and does not necessarily lead to motility [Ducret et al., 2012]. The slime trails from A-motile cells can be tracked by S-motile cells via the TFP. Following the trails, S-motile cells also find the new favourable habitats [MuñozDorado et al., 2016].

\section{The Variety of Predatory Bacteria of Cyanobacteria}

Predatory bacteria like Bdellovibrio and Myxococcus have been the focus of intense research efforts. In contrast, bacterial predators of cyanobacteria remain largely uncharacterized. The following part summarizes the current state of knowledge about predatory bacteria described to use cyanobacteria as prey. Most of them belong to the phyla Bacteroidetes and Proteobacteria, with the exception of Bacillus cereus, assigned to the Firmicutes (Fig. 4). B. cereus is able to lyse a variety of cyanobacteria within the species Aphanizomenon flos-aquae, Microcystis viridis, Microcystis wesenbergi, Microcystis aeruginosa, Oscillatoria tenuis, Nostoc punctiforme, Anabaena flosaquae, and Arthrospira maxima. The lysing mechanism is not clear, but in case of $A$. flos-aquae, B. cereus attaches to the prey cell [Shunyu et al., 2006]. In contrast to that, in another study the supernatant of B. cereus was sufficient to lyse Microcystis [Nakamura et al., 2003], suggesting that $B$. cereus may use different strategies to kill different prey.

Within the phylum Proteobacteria, in addition to Bdellovibrio and Myxococcus, there are three genera with predators of cyanobacteria. The genus Kaistia belongs to the Alphaproteobacteria. Two strains of so-called ultramicrobacteria lyse Acidovorax spp., Bacillus spp., and several cyanobacteria. Ultramicrobacteria have a cell volume smaller than $0.1 \mu \mathrm{m}^{3}$ and a genome size of $\sim 3.2$ to $\sim 0.58$ $\mathrm{Mb}$, and the cell size of the bacteria remains small regardless of the cultivation [Duda et al., 2012]. These facultative epibiotic predators of Kaistia lyse Anabaena variabilis, 
Fig. 5. Cluster of 48 environmental water isolates by their predatory behaviour. Isolates were clustered by their ability to lyse prey bacteria of the order Nostocales and Synechococcales taking into account the nitrate level of the medium. Group A: only Anabaena spp. on nitrate-free BG11 medium were lysed. Group B: nostocales and Synechococcales were lysed. The medium had no effect. Group C: only Nostocales were lysed. Group D: only A. variabilis on standard BG11 medium was not lysed.

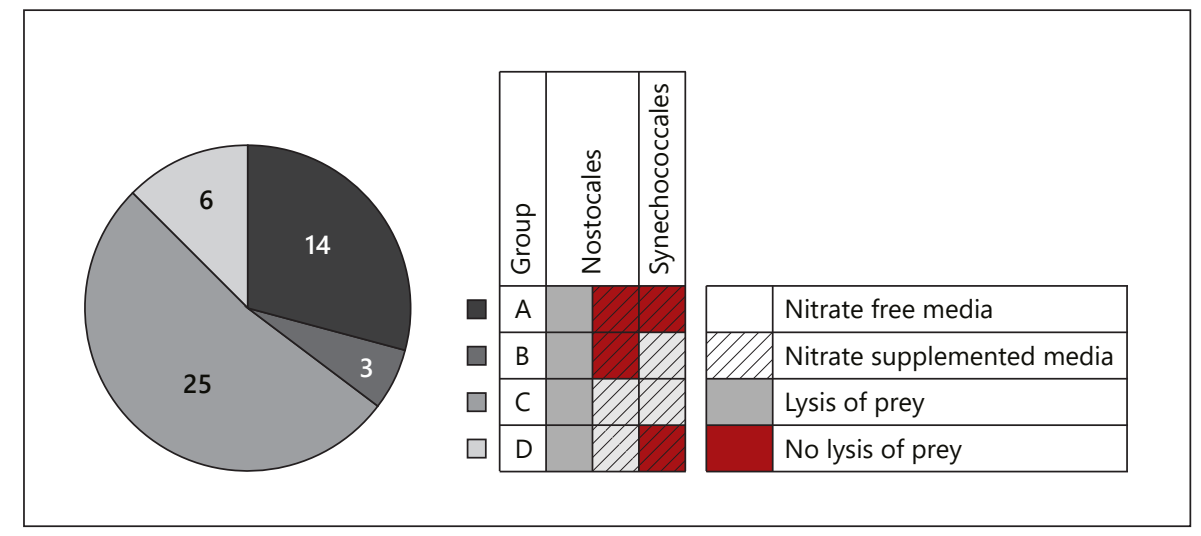

Nostoc muscorum, and Chlorogloeopsis fritschii. The bacteria attach to the prey cell, penetrate the sheath, and in some cases infiltrate the cell. The authors suggest that the infiltration of the cell happens after the cell death of the prey bacterium. One strain is reported to preferably lyse the nitrogen fixing cells of $A$. variabilis, termed heterocysts, and the spore-like cells, called akinetes [Duda et al., 2009]. Achromobacter denitrificans, a betaproteobacterium (former Alcaligenes denitrificans) preys on Microcystis by direct cell-cell contact, but the lysing mechanism remains unclear [Pathmalal et al., 2000; Coenye et al., 2003].

Before taxonomic classification by $16 \mathrm{~S}$ analysis was possible, predatory bacteria of the genus Lysobacter (Gammaproteobacteria) were often falsely assigned to the genus Myxococcus [Christensen and Cook, 1978]. Shilo [1970] described a bacterium of the genus Lysobacter that lyses its prey by direct contact, that is, by attaching the tip of the predator's cell to the prey bacterium. Lysobacter's prey belong to the species Leptolyngbya boryana, Oscillatoria prolifera, Arthrospira platensis, Arthrospira tenuis, Nostoc sp., Asterocapsa nidulans, and Cyanobacterium staniera (names correspond to the current taxonomy). In case of heterocyst-forming species, only vegetative cells are lysed. The cell envelope of vegetative cells consists of an inner membrane, a periplasmic space, a peptidoglycan layer, and the outer membrane. Heterocysts are surrounded by an additional glycolipid layer (reviewed by Nicolaisen et al. [2009]). This extra feature could protect from predatory bacteria. However, heterocysts are terminally differentiated and do not reproduce any more. Therefore, the vegetative cells are not protected by the additional glycolipid layer of the heterocyst.

In the phylum Bacteroidetes, four predators of cyanobacteria are known. Saprospira grandis is a Gram-negative bacterium that forms spiral-shaped filaments of several cells and was isolated from marine habitat [Lewin,
1997]. It belongs to the class Saprospiria and catches prey by attachment to the prey's flagellum. Shi et al. [2006] isolated a Saprospira strain that preys on Anabaena spp. by moving as a bundle of cells. Many filaments of the predator surround the prey cells and lyse them. Predation by the closely related species Saprospira albida leads to colourless Microcystis cells, a distinctive sign of cell death of the prey [Ashton and Robarts, 1987]. Flexibacter flexilis of the order Cytophagales lyses Oscillatoria williamsii. It attaches to the sheaths of the cyanobacterial cell and excretes lysozyme. The prey cell lyses and the predator takes up the resulting compounds [Sallal, 1994]. The last two predators belong to the family Cytophagaceae. Fibrella aestuarina is likely to establish physical contact with its prey $N$. muscorum as treatment with the supernatant induced no lysis [Svercel et al., 2011]. Bacteria of the genus Cytophaga lyse several cyanobacterial strains. In their study, Rashidan and Bird [2001] isolated two Cytophaga strains from Brome Lake in Canada, both predating cyanobacteria. With direct cell-cell contact, strain 1 lysed only A.flos-aquae, whereas strain 2 lysed only Synechococcus sp. and $A$. nidulans. This indicates that bacteria belonging to the same genus and isolated from the same source can still have a different prey spectrum.

\section{Occurrence of Bacterial Predators of Cyanobacteria in Common Freshwater Samples}

To get an overview over the occurrence of bacterial predators of cyanobacteria in freshwater samples, we screened for predatory bacteria using the cyanobacterial strain A. variabilis PCC 7937 as a model prey. Forty-eight isolates containing lytic activity were obtained and clustered in four different groups, according to their ability to prey on either diazotrophic- or nitrate-grown Anabaena 
cells, as well as on the unicellular cyanobacteria Synechococcus elongatus PCC 7942 and Synechocystis PCC 6803 on nitrate-supplemented medium (see Fig. 5). The detailed experimental procedure is provided in the supplemental material (for all online suppl. material, see www. karger.com/doi/10.1159/000516427).

The 14 isolates of group A were only able to prey on $A$. variabilis and Anabaena PCC 7120 on nitrate-free media, whereas no lysis occurred on nitrate-supplemented BG11 medium. They also did not lyse the tested non-diazotrophic unicellular strains Synechococcus and Synechocystis, grown on nitrate-supplemented media. Hence, these predators probably lyse the cyanobacteria as a source of combined nitrogen, which would explain why predation is supressed by high nitrate concentrations. In this case, the isolates would behave as facultative predators. Another possibility is that the high nitrate content in BG11 is, directly or indirectly, toxic for the predators. Normally, the nitrate level in surface water lies between 0 and $18 \mathrm{mg} / \mathrm{L}$ and does not naturally exceed over 4-9 mg/L [World Health, 2003]. Due to agricultural fertilizers, levels can rise up to $1,500 \mathrm{mg} / \mathrm{L}$ which was shown for groundwater in an agricultural area in India [Jacks and Sharma, 1983]. The standard BG11 medium contains $1,085 \mathrm{mg} / \mathrm{L}$ nitrate $\left(1,495 \mathrm{mg} / \mathrm{L} \mathrm{NaNO}_{3}\right)$, which is higher than most naturally occurring levels of nitrate and might be unfavourable for the predators. In nature, it is likely that filamentous cyanobacteria do form heterocysts at the low naturally occurring levels of nitrate.

The isolates in group B (3 isolates) did not lyse the non-heterocystous $A$. variabilis on nitrate-supplemented media but the heterocyst containing A. variabilis and $A n$ abaena PCC7120 on nitrate-free media. The Synechococcales on nitrate-supplemented media were also lysed, which means the nitrate itself is not responsible for the lack of lysis. It is possible that the metabolic state of the nitrate-grown Anabaena makes them resistant to predation by the organisms in group B.

The isolates from group $\mathrm{C}$ showed a rather unspecific prey spectrum as they lysed all the tested cyanobacteria on all tested media. The predatory bacterium B. cereus (Firmicutes) has also a broad prey spectrum within the cyanobacteria, as mentioned above [Shunyu et al., 2006]. Obviously, there are certain predators with a broad prey spectrum. While group $\mathrm{C}$ seems unspecific, the members of group D (6 isolates) appear to be specific for the tested cyanobacteria of the order Nostocales, as the Synechococcales were not lysed. In the study of Rashidan and Bird [2001], one isolate of Cytophaga lysed only the tested filamentous cyanobacterium, and the second isolate, from the same source, only lysed the tested unicellular cyanobacteria.
Hence, the prey spectrum of strains from the same genus and the same source can still be different. The isolates of groups $\mathrm{C}$ and $\mathrm{D}$ were both taken from the Schwarzenbachtalsperre in Forbach, Germany. It is possible that the predators of both groups belong to the same genus but have, as in the case of Cytophaga sp., a different prey spectrum.

The isolates were observed under the microscope in a random sample survey. All observed isolates contained bacteria. Some also contained fungi. Most isolates (31 isolates) showed lytic activity after filtration with a pore size of $0.45 \mu \mathrm{m}$. Ultramicrobacteria like Kaistia and Bdellovibrios/BALOs with the smallest size of $0.2 \mu \mathrm{m}$ in width and $0.5 \mu \mathrm{m}$ in length can pass a $0.45-\mu \mathrm{m}$ filter [Rendulic et al., 2004; Duda et al., 2009]. In rare cases, they could theoretically also pass through the $0.22-\mu \mathrm{m}$ filter. Even so, no isolate retained lytic activity after filtration through a $0.22-\mu \mathrm{m}$ filter. This also excludes most cyanophages as source of lysis [Chen and Lu, 2002; Sullivan et al., 2005; Pope et al., 2007]. Some, however, like the cyanomyovirus AS-1 measure over $0.3 \mu \mathrm{m}$ (90 $\mathrm{nm}$ head, $243 \mathrm{~nm}$ tail) [Sar$\mathrm{ma}, 2012]$. Therefore, microorganisms in this fraction $(0.22-0.45 \mu \mathrm{m})$ can be bacteria or large myoviruses. Two isolates lost their lytic activity after $0.45 \mu \mathrm{m}$ filtration and hence contain predators with a size between 1 and 0.45 $\mu \mathrm{m}$. From the above-mentioned considerations, we deduce that these predators are likely to be bacteria. In 15 isolates, lytic activity was already lost after filtration through a $1-\mu \mathrm{m}$ filter. These isolates probably consist of larger predators. These could be organisms such as $M$. xanthus which forms vegetative cells of $7 \mu \mathrm{m}$ in length and $0.5 \mu \mathrm{m}$ in width and spherical spores of $1.7 \mu \mathrm{m}$ in diameter [Müller et al., 2012]. Both would rather not pass through a $1-\mu \mathrm{m}$ filter. Another example, S. grandis, forms long filaments from 10 to $500 \mu \mathrm{m}$ [Reichenbach, 2006]. Besides big predatory bacteria, those isolates can contain protozoa $(1 \mu \mathrm{m}$ to several $\mathrm{mm})$ and fungi $(>10 \mu \mathrm{m}$ hyphae, $>1 \mu \mathrm{m}$ spores) [Singleton and Sainsbury, 2001; Yamamoto et al., 2012]. Because the lysis of $A$. variabilis on nitrate-free agar plates was not impaired when the antifungals nystatin and cycloheximide were added, fungi can largely be excluded as source of lysis. No correlation was detected between the prey-specific grouping of the predator and their size.

\section{Conclusion}

When it comes to predation of cyanobacteria, the literature provides a plethora of research articles about grazing and cyanophages and their impact on cyanobac- 
terial blooms. Those systems are well studied. But the importance and occurrence of bacterial predators of cyanobacteria is still underestimated. As reviewed in this article, only few bacteria are known to prey on cyanobacteria. The published studies mainly focused on the presence of the predator but did not investigate the mechanisms of lysis or the prey spectrum in much detail. In our screening experiment, we found predators of different size and predation behaviour indicating the existence of a variety of bacterial predators of cyanobacteria.

Because of agricultural fertilization, high nitrate levels occur in natural systems and can promote bloom formation. We found indications that high nitrate levels impair bacterial predation. It needs to be investigated if the explosive growth of cyanobacteria and a loss of predatory activity could be a double-negative effect of high nitrate levels in freshwater systems.
In future, bacterial predation could be a new approach to control cyanobacterial blooms; however, intensive research efforts are required to pursue this aim.

\section{Conflict of Interest Statement}

The authors have no conflicts of interest to declare.

\section{Funding Sources}

This work was funded by the GRK 1708 - Molecular principles of bacterial survival strategies. We further acknowledge support by Open Access Publishing Fund of University of Tübingen.

\section{Author Contributions}

Conceptualization: K.F.; writing-original draft preparation: A.B.; review and editing: A.B and K.F.

\section{References}

Ashton PJ, Robarts RD. Apparent Predation of Microcystis aeruginosa Kütz. Emend Elenkin by a Saprospira-like Bacterium in a Hypertrophic Lake (Hartbeespoort Dam, South Africa). J Limnol Soc S Afr. 1987 1987/01/01;13(1):44-7.

Behmlander RM, Dworkin M. Biochemical and structural analyses of the extracellular matrix fibrils of Myxococcus xanthus. J Bacteriol. 1994 Oct;176(176):6295-303.

Boucher DH, SJ, SKH . The Ecology of Mutualism. Annu Rev Ecol Syst. 1982;13(1):315-47.

Keeler TC, del Giorgio PA. Compositional changes in free-living bacterial communities along a salinity gradient in two temperate estuaries. Limnol Oceanogr. 2002;47(2):453-70.del

Bowden MG, Kaplan HB. The Myxococcus xanthus lipopolysaccharide $\mathrm{O}$-antigen is required for social motility and multicellular development. Mol Microbiol. 1998 Oct;30(2):275-84.

Bretscher AP, Kaiser D. Nutrition of Myxococcus xanthus, a fruiting myxobacterium. J Bacteriol. 1978 Feb;133(2):763-8.

Burnham JC, Stetak T, Locher G. Extracellular Lysis of the Bluegreen Alga Phormidium Luridum by Bdellovibrio Bacteriovorus 1. J Phycol. 1976;12(3):306-13.

Burnham JC, Collart SA, Highison BW. Entrapment and lysis of the cyanobacterium Phormidium luridum by aqueous colonies of Myxococcus xanthus PCO2. Arch Microbiol. 1981 1981/06/01;129(4):285-94.

Caiola MG, Pellegrini S. Lysis of Microcystis aeruginosa (Kütz.) by Bdellovibrio-like Bacteria. J Phycol. 1984;20(4):471-5.

Capeness MJ, Lambert C, Lovering AL, Till R, Uchida K, Chaudhuri R, et al. Activity of Bdellovibrio hit locus proteins, Bd0108 and
Bd0109, links Type IVa pilus extrusion/retraction status to prey-independent growth signalling. PLoS One. 2013;8(11):e79759.

Chen F, Lu J. Genomic sequence and evolution of marine cyanophage P60: a new insight on lytic and lysogenic phages. Appl Environ Microbiol. 2002 May;68(5):2589-94.

Christensen P, Cook FD. Lysobacter, a New Genus of Nonfruiting, Gliding Bacteria with a High Base Ratio. Int J Syst Bacteriol. 1978; 28(3):367-93.

Coenye T, Vancanneyt M, Cnockaert MC, Falsen E, Swings J, Vandamme P. Kerstersia gyiorum gen. nov., sp. nov., a novel Alcaligenes faecalis-like organism isolated from human clinical samples, and reclassification of Alcaligenes denitrificans Rüger and Tan 1983 as Achromobacter denitrificans comb. nov. Int J Syst Evol Microbiol. 2003 Nov;53(Pt 6):1825-31.

Dryden RC, Wright SJL. Predation of cyanobacteria by protozoa. Can J Microbiol. 1987; 33(6):471-82

Ducret A, Valignat M-P, Mouhamar F, Mignot T, Theodoly O. Wet-surface-enhanced ellipsometric contrast microscopy identifies slime as a major adhesion factor during bacterial surface motility. Proc Natl Acad Sci USA. 2012; 109(109):10036-41.

Duda VI, Suzina NE, Esikova TZ, Akimov VN, Oleinikov RR, Polivtseva VN, et al. A cytological characterization of the parasitic action of ultramicrobacteria NF1 and NF3 of the genus Kaistia on chemoorganotrophic and phototrophic bacteria. FEMS Microbiol Ecol. 2009;69(2):180-93

Duda VI, Suzina NE, Polivtseva VN, Boronin AM. Ultramicrobacteria: Formation of the concept and contribution of ultramicrobacteria to biology. Microbiology. 2012 2012;81(4):379-90.

Esteves AI, Cullen A, Thomas T. Competitive interactions between sponge-associated bacteria. FEMS Microbiol Ecol. 2017 Mar 1;93(3).

Evans KJ, Lambert C, Sockett RE. Predation by Bdellovibrio bacteriovorus HD100 Requires Type IV Pili. J Bacteriol. 2007;189(189):4850-9.

Gerphagnon M, Latour D, Colombet J, SimeNgando T. Fungal parasitism: life cycle, dynamics and impact on cyanobacterial blooms. PLoS One. 2013;8(4):e60894.

Gilbert JA, Steele JA, Caporaso JG, Steinbrück L, Reeder J, Temperton B, et al. Defining seasonal marine microbial community dynamics. ISME J. 2012 2012;6(6):298-308.

Gonze D, Coyte KZ, Lahti L, Faust K. Microbial communities as dynamical systems. Curr Opin Microbiol. 2018;44(44):41-9.

Hahn MW, Schmidt J, Koll U, Rohde M, Verbarg $\mathrm{S}$, Pitt A, et al. Silvanigrella aquatica gen. nov., sp. nov., isolated from a freshwater lake, description of Silvanigrellaceae fam. nov. and Silvanigrellales ord. nov., reclassification of the order Bdellovibrionales in the class Oligoflexia, reclassification of the families Bacteriovoracaceae and Halobacteriovoraceae in the new order Bacteriovoracales ord. nov., and reclassification of the family Pseudobacteriovoracaceae in the order Oligoflexales. Int J Syst Evol Microbiol. 2017 Aug;67(8):2555-68.

Harding CJ, Huwiler SG, Somers H, Lambert C, Ray LJ, Till R, et al. A lysozyme with altered substrate specificity facilitates prey cell exit by the periplasmic predator Bdellovibrio bacteriovorus. Nat Commun. 2020 2020;11(11): 4817. 
Herencias C, Salgado-Briegas S, Prieto MA, Nogales J. Providing new insights on the biphasic lifestyle of the predatory bacterium Bdellovibrio bacteriovorus through genome-scale metabolic modeling. PLoS Comput Biol. 2020 Sep;16(16):e1007646.

Huisman J, Codd GA, Paerl HW, Ibelings BW, Verspagen JMH, Visser PM. Cyanobacterial blooms. Nat Rev Microbiol. 2018;16(8):47183.

Huson DH, Scornavacca C. Dendroscope 3: An Interactive Tool for Rooted Phylogenetic Trees and Networks. Syst Biol. 2012;61(61): 1061-7.

Jacks G, Sharma VP. Nitrogen circulation and nitrate in groundwater in an agricultural catchment in Southern India. Geo. 1983;5(2):61-4.

Kaiser D. Social gliding is correlated with the presence of pili in Myxococcus xanthus. Proc Natl Acad Sci USA. 1979 Nov;76(76):5952-6.

Koval SF, Hynes SH. Effect of paracrystalline protein surface layers on predation by Bdellovibrio bacteriovorus. J Bacteriol. 1991 Apr; 173(7):2244-9.

Koval SF, Hynes SH, Flannagan RS, Pasternak Z Davidov Y, Jurkevitch E. Bdellovibrio exovorus sp. nov., a novel predator of Caulobacter crescentus. Int J Syst Evol Microbiol. 2013 Jan;63(63):146-51.

Kuru E, Lambert C, Rittichier J, Till R, Ducret A, Derouaux A, et al. Fluorescent D-amino-acids reveal bi-cellular cell wall modifications important for Bdellovibrio bacteriovorus predation. Nat Microbiol. 2017 Dec;2(12):164857.

Lerner TR, Lovering AL, Bui NK, Uchida K, Aizawa S, Vollmer W, et al. Specialized peptidoglycan hydrolases sculpt the intra-bacterial niche of predatory Bdellovibrio and increase population fitness. PLoS Pathog. 2012 Feb; 8(8):e1002524.

Lewin RA. Saprospira grandis: A Flexibacterium That Can Catch Bacterial Prey by "Ixotrophy”. Microb Ecol. 1997;34(3):232-6.

Li Y, Sun H, Ma X, Lu A, Lux R, Zusman D, et al. Extracellular polysaccharides mediate pilus retraction during social motility of Myxococcus xanthus. Proc Natl Acad Sci USA. 2003; 100(100):5443-8

Livingstone PG, Morphew RM, Whitworth DE. Myxobacteria Are Able to Prey Broadly upon Clinically-Relevant Pathogens, Exhibiting a Prey Range Which Cannot Be Explained by Phylogeny. Front Microbiol. 2017 Aug 22(1593):8.

Lloyd DG, Whitworth DE. The Myxobacterium Myxococcus xanthus Can Sense and Respond to the Quorum Signals Secreted by Potential Prey Organisms. Front Microbiol. 2017 March 14;8(439).

Lu A, Cho K, Black WP, Duan XY, Lux R, Yang $Z$, et al. Exopolysaccharide biosynthesis genes required for social motility in Myxococcus xanthus. Mol Microbiol. 2005 Jan;55(1):20620.

Ma AT, Daniels EF, Gulizia N, Brahamsha B. Isolation of diverse amoebal grazers of freshwa- ter cyanobacteria for the development of model systems to study predator-prey interactions. Algal Res. 2016;13:85-93.

McBride MJ, Zusman DR. Behavioral analysis of single cells of Myxococcus xanthus in response to prey cells of Escherichia coli. FEMS Microbiol Lett. 1996 Apr 1;137(2-3): 227-31.

Merz AJ, So M, Sheetz MP. Pilus retraction powers bacterial twitching motility. Nature. 2000 Sep 7;407(407):98-102.

Morgan AD, MacLean RC, Hillesland KL, Velicer GJ. Comparative analysis of myxococcus predation on soil bacteria. Appl Environ Microbiol. 2010 Oct;76(20):6920-7.

Müller FD, Schink CW, Hoiczyk E, Cserti E, Higgs PI. Spore formation in Myxococcus xanthus is tied to cytoskeleton functions and polysaccharide spore coat deposition. Mol Microbiol. 2012;83(3):486-505.

Muñoz-Dorado J, Marcos-Torres FJ, García-Bravo E, Moraleda-Muñoz A, Pérez J. Myxobacteria: Moving, Killing, Feeding, and Surviving Together. Front Microbiol. 2016 May 26; 7(781):781.

Nakamura N, Nakano K, Sugiura N, Matsumura M. A novel cyanobacteriolytic bacterium, Bacillus cereus, isolated from a Eutrophic Lake. J Biosci Bioeng. 2003;95(2):179-84.

NCBI [Internet], NCBI [Internet]. NCBI Common Tree[2020-Dec-22]. Available from https: //www.ncbi.nlm.nih.gov/Taxonomy/ CommonTree/wwwcmt.cgi

Nicolaisen K, Hahn A, Schleiff E. The cell wall in heterocyst formation by Anabaena sp. PCC 7120. J Basic Microbiol. 2009 Feb;49(1):5-24.

Pan H, He X, Lux R, Luan J, Shi W. Killing of Escherichia coli by Myxococcus xanthus in aqueous environments requires exopolysaccharide-dependent physical contact. Microb Ecol. 2013 Oct;66(3):630-8.

Pathmalal MM, Zen'ichiro K, Shin-ichi N. Algicidal effect of the bacterium Alcaligenes denitrificans on Microcystis spp. Aquatic Microb Ecol. 2000;22(2):111-7.

Pérez J, Jiménez-Zurdo JI, Martínez-Abarca F, Millán V, Shimkets LJ, Muñoz-Dorado J. Rhizobial galactoglucan determines the predatory pattern of Myxococcus xanthus and protects Sinorhizobium meliloti from predation. Environ Microbiol. 2014 Jul;16(16): 2341-50.

Pope WH, Weigele PR, Chang J, Pedulla ML, Ford ME, Houtz JM, et al. Genome sequence, structural proteins, and capsid organization of the cyanophage Syn5: a "horned" bacteriophage of marine synechococcus. J Mol Biol. 2007 May 11;368(4):966-81.

Rashidan KK, Bird DF. Role of predatory bacteria in the termination of a cyanobacterial bloom. Microb Ecol. 2001;41(41):97-105.

Reichenbach H. The Genus Saprospira. In: Dworkin M, Falkow S, Rosenberg E, Schleifer K-H, Stackebrandt E, editors. The Prokaryotes: Volume 7: Proteobacteria: Delta, Epsilon Subclass. New York: Springer; 2006. p. 591601.
Rendulic S, Jagtap P, Rosinus A, Eppinger M, Baar C, Lanz C, et al. A predator unmasked: life cycle of Bdellovibrio bacteriovorus from a genomic perspective. Science. 2004 Jan 30; 303(303):689-92.

Rosenberg E, Varon M. Antibiotics and lytic enzymes. In: Rosenberg E, editor. Myxobacteria: Development and Cell Interactions. New York: Springer; 1984. p. 109-25

Rotem O, Pasternak Z, Jurkevitch E. Bdellovibrio and Like Organisms. In: Rosenberg E, DeLong EF, Lory S, Stackebrandt E, Thompson F, editors. The Prokaryotes: Deltaproteobacteria and Epsilonproteobacteria. Berlin: Springer; 2014. p. 3-17.

Sallal AK. Lysis of cyanobacteria with Flexibacter spp isolated from domestic sewage. Microbios. 1994;77(310):57-67.

Sarma TA. Handbook of Cyanobacteria. Milton Park: Taylor \& Francis; 2012.

Shi M, Zou L, Liu X, Gao Y, Zhang Z, Wu W, et al. A novel bacterium Saprospira sp. strain PdY3 forms bundles and lyses cyanobacteria. Front Biosci. 2006 May 1;11(11):1916-23.

Shilo M. Lysis of Blue-Green Algae by Myxobacter. J Bacteriol. 1970;104(1):453-61.

Shimkets LJ. Nutrition, Metabolism, and the Initiation of Development. In: Rosenberg E, editor. Myxobacteria: Development and Cell Interactions. New York: Springer; 1984. p. 91107.

Shunyu S, Yongding L, Yinwu S, Genbao L, Dunhai L. Lysis of Aphanizomenon flos-aquae (Cyanobacterium) by a bacterium Bacillus cereus. Biol Control. 2006 2006/12/01/;39(3): $345-51$

Simkovsky R, Daniels EF, Tang K, Huynh SC, Golden SS, Brahamsha B. Impairment of Oantigen production confers resistance to grazing in a model amoeba-cyanobacterium predator-prey system. Proc Natl Acad Sci USA. 2012 Oct 9;109(109):16678-83.

Singleton P, Sainsbury D. Dictionary of Microbiology and Molecular Biology . London: Wiley; 2001.

Spagnolie SE, Lauga E. Jet propulsion without inertia. Phys Fluids. 2010;22(8):081902.

Stolp H, Petzold H. Untersuchungen über einen obligat parasitischen Mikroorganismus mit lytischer Aktivität für Pseudomonas-Bakterien. J Phytopathol. 1962;45(4):364-90.

Stolp H, Starr MP. Bdellovibrio bacteriovorus gen. et sp. n., a predatory, ectoparasitic, and bacteriolytic microorganism. Antonie van Leeuwenhoek. 1963 1963;29(1):217-48.

Straley SC, Conti SF. Chemotaxis by Bdellovibrio bacteriovorus toward prey. J Bacteriol. 1977 Nov;132(132):628-40.

Straley SC, LaMarre AG, Lawrence LJ, Conti SF. Chemotaxis of Bdellovibrio bacteriovorus toward pure compounds. J Bacteriol. 1979; 140(2):634-42.

Sullivan MB, Coleman ML, Weigele P, Rohwer F, Chisholm SW. Three Prochlorococcus cyanophage genomes: signature features and ecological interpretations. PLoS Biol. 2005 May;3(3):e144. 
Sun H, Zusman DR, Shi W. Type IV pilus of Myxococcus xanthus is a motility apparatus controlled by the frz chemosensory system. Curr Biol. 2000 Sep 21;10(18):1143-6.

Svercel M, Saladin B, van Moorsel SJ, Wolf S, Bagheri HC. Antagonistic interactions between filamentous heterotrophs and the cyanobacterium Nostoc muscorum. BMC Res Notes. 2011 Sep 13;4(4):357.

Thiery S, Kaimer C. The Predation Strategy of Myxococcus xanthus. Front Microbiol. 2020 2020-January-14;11(11):2.

Thomashow MF, Rittenberg SC. Intraperiplasmic growth of Bdellovibrio bacteriovorus 109J: Ndeacetylation of Escherichia coli peptidoglycan amino sugars. J Bacteriol. 1978a Sep; 135(3):1008-14.
Thomashow MF, Rittenberg SC. Intraperiplasmic growth of Bdellovibrio bacteriovorus 109J: solubilization of Escherichia coli peptidoglycan. J Bacteriol. 1978b Sep;135(135):9981007.

Usher KM, Bergman B, Raven JA. Exploring Cyanobacterial Mutualisms. Annu Rev Ecol Evol Syst. 2007;38(1):255-73.

Wolgemuth C, Hoiczyk E, Kaiser D, Oster G. How myxobacteria glide. Curr Biol. 2002 Mar 5;12(12):369-77.

World Health O. Nitrate and Nitrite in DrinkingWater: Background Document for Development of WHO Guidelines for Drinking-Water Quality. Geneva: World Health Organization; 2003.

Wright SJL, Redhead K, Maudsley H. Acanthamoeba castellanii, a Predator of Cyanobacteria. Microbiology. 1981;125(2):293-300.
Yamamoto N, Bibby K, Qian J, Hospodsky D, Rismani-Yazdi H, Nazaroff WW, et al. Particlesize distributions and seasonal diversity of allergenic and pathogenic fungi in outdoor air. ISME J. 2012 Oct;6(6):1801-11.

Zeng G, Wang P, Wang Y. Algicidal efficiency and mechanism of Phanerochaete chrysosporium against harmful algal bloom species. $\mathrm{Al}-$ gal Res. 2015;12:182-90.

Zeng G, Gao P, Wang J, Zhang J, Zhang M, Sun D. Algicidal Molecular Mechanism and Toxicological Degradation of Microcystis aeruginosa by White-Rot Fungi. Toxins (Basel). 2020 Jun 19;12(12).

Zhang W, Wang Y, Lu H, Liu Q, Wang C, Hu W, et al. Dynamics of Solitary Predation by Myxococcus xanthus on Escherichia coli Observed at the Single-Cell Level. Appl Environ Microbiol. 2020;86(3):e02286-19. 